\title{
AKUNTABILITAS PENGELOLAAN ANGGARAN PENDAPATAN DAN \\ BELANJA DESA (Studi Kasus Desa Bluru Kidul Kecamatan Sidoarjo)
}

*Ade Olivia Saragih, Arief Rahman, Tri Lestari

Program Studi Akuntansi Fakultas Ekonomi dan Bisnis

Universitas Bhayangkara Surabaya, Indonesia

DOI: https://doi.org/10.46821/equity.v1i1.3

\begin{abstract}
ABSTRAK
Penelitian ini membahas Akuntabilitas Pengelolaan Anggaran Pendapatan dan Belanja Desa (APBDes) dengan tujuan untuk mendeskripsikan Akuntabilitas Pemerintah Desa dalam Pengelolaan Anggaran Pendapatan dan Belanja Desa (APBDes) Tahun 2017. Penelitian ini dilakukan untuk mengetahui prinsip akuntabilitas mulai dari perencanaan, pelaksanaan, penatausahaan, laporan pertanggungjawaban. Pendekatan penelitian ini menggunakan kualitatif deskriptif. Hasil penelitian ini menunjukkan bahwa prinsip akuntabilitas dalam pengelolaan Anggaran Pendapatan dan Belanja Desa (APBDes) Tahun 2017 di desa Bluru Kidul Kecamatan Sidoarjo secara bertahap mulai dari tahap perencanaan, pelaksanaan, penatausahaan sampai pada tahap pelaporan dan pertanggung jawaban APBDes telah sesuai dengan Permendagri No.113 tahun 2014, namun pemerintah desa belum transparan terhadap masyarakat. sisi pengelolaan administrasi keuangan dalam pertanggunjawaban masih diperlukan adanya pembinaan dan pengawasan.
\end{abstract}

Kata kunci: Pengelolaan Anggaran Pendapatan dan Belanja Desa (APBDes), Akuntabilitas, Kecamatan Sidoarjo.

\section{ABSTRACT}

This study discusses the application of Village Revenue and Expenditure Budget Management Accountability (APBDes) with the aim to describe Village Government Accountability in Village Revenue and Expenditure Management (APBDes) Year 2017. This research is conducted to know gradually start from the planning, implementation, administration until the reporting and accountability stage APBDes has been in accordance with Permendagri No.113, year 2017 in bluru kidul kecamatan sidoarjo village. But the village government has not been transparent to the community. The management side of financial administration in accountability still needs guidance and supervision.

Keywords: Village Revenue and Expenditure Budget (APBDes), Accountability, Bluru Kidul District.

*Corresponding Author:

Email: saragihadeolivia@gmail.com 


\section{PENDAHULUAN}

Desa tidak terpisahkan dari penyelenggaraan otonomi daerah, dan pemerintahan desa merupakan unit terdepan (ujung tombak) dalam pelayanan kepada masyarakat sehingga menjadi tonggak yang strategis untuk keberhasilan semua program yang telah direncanakan. Akuntabilitas kinerja pemerintah adalah perwujudan kewajiban suatu instansi pemerintah untuk mempertanggungjawabkan pelaksanaan misi organisasi dalam mencapai tujuan dan sasaran yang telah ditetapkan melalui alat pertanggungjawaban secara periodik (Riantiarno, 2014). Prinsip Akuntabilitas Pengelolaan Anggaran Pendapatan dan Belanja Desa (APBDes) mulai dari perencanaan, penatausahaan, pelaksanaan, pelaporan dan pertanggungjawaban sangat penting dalam pengelolaan dana desa. sehingga perlu untuk mengetahui Prinsip akuntabilitas di desa tersebut sudah berjalan dengan baik atau tidak. Prinsip akuntabilitas Desa Bluru Kidul Kecamatan Sidoarjo sudah berjalan dengan baik, namun ada beberapa hal yang belum terpenuhi yakni, dari segi laporan pertanggungjawaban terhadap APBDes yang belum optimal dikarenakan laporan pertanggungjawaban APBDes belum transparannya pemerintah desa dalam laporan pertanggungjawaban kegiatan dalam satu tahun dan sering terjadinya keterlambatan laporan realisasi pertanggungjawaban APBDes. sehingga dalam penerapan prinsip akuntabilitas perlu adanya pembinaan dan pengawasan dana desa guna mendukung pertanggungjawaban APBDes dan sesuai dengan Peraturan Desa tentang APBDes. Dengan demikian Akuntabilitas Pengelolaan APBDes sangat dibutuhkan untuk mendorong pembangunan desa agar berjalan dengan baik. Peneliti memiliki alasan tersendiri dalam memilih program APBDes. Ketertarikan ini dikarenakan APBDes memiliki implikasi yang besar dalam pembangunan sebuah desa. Faktor lain yang mendorong penulis dalam melakukan penelitian ini juga ingin mengetahui mengenai transparansi pengelolaan APBDes dan sistem pengawasan yang dapat meminimalkan terjadinya korupsi anggaran desa di desa Bluru Kidul Kecamatan Sidoarjo untuk itu perlu adanya studi mendalam untuk mengkaji “ Akuntabilitas Pengelolaan Anggaran Pendapatan Dan Belanja Desa (APBDes) di Desa Bluru Kidul Kecamatan Sidoarjo". Tujuan dari penelitian ini adalah untuk mengetahui Prinsip Akuntabilitas Pengelolaan Anggaran Pendapatan dan Belanja Desa Di Desa Bluru Kidul Kecamatan Sidoarjo.

\section{LANDASAN TEORI}

\section{Pengertian Akuntabilitas}

Akuntabilitas adalah kewajiban untuk memberikan pertanggungjawaban atau menjawab dan menerangkan kinerja serta tindakan seseorang / pimpinan suatu unit organisasi kepada pihak yang memiliki hak atau yang berwenang meminta pertanggungjawaban. 
Akuntabilitas semakin baik jika didukung oleh suatu sistem akuntansi yang menghasilkan informasi yang akurat, handal, tepat waktu, serta dapat dipertanggungjawabkan (Komang, 2014).

\section{Perencanaan}

Berdasarkan Peraturan Pemerintah Nomor 43 tahun 2014 Perencanaan APBDes adalah proses pemikiran dan penentuan secara matang untuk mencapai suatu tujuan dalam pengelolaan keuangan desa dalam hal kegiatan pembanguan maupun pemberdayaan masyarakat.

\section{Pelaksanaan}

Berdasarkan Peraturan Pemerintah Nomor 43 tahun 2014 Pelaksanaan APBDes adalah proses dimana peraturan desa tentang APBDes yang telah ditetapkan sebelumnya dilaksanakan dalam rangka pelaksanaan kegiatan pemerintahan desa dalam pelayanan, pembangunan maupun dalam pemberdayaan. Semua pelaksanaan yang terkait dengan keuangan desa harus disertai dengan bukti yang lengkap dan sah.

\section{Panatausahaan}

Berdasarkan Peraturan Pemerintah Nomor 43 tahun 2014 Penatausahaan adalah proses dimana semua kegiatan/pelaksanaan keuangan desa dikelola dan dicatat dalam buku-buku tertentu oleh bendahara desa yang sebelumnya telah ditetapkan oleh kepala desa dengan keputusan kepala desa.

\section{Pelaporan dan Pertanggungjawaban}

Berdasarkan Peraturan Pemerintah Nomor 43 tahun 2014 Laporan APBDes adalah proses hasil kegiatan dari penatausahaan keuangan desa dikelola dan disampaikan oleh pemerintah desa kepada BPD, pengawas dan masyarakat sedangkan Tanggung jawab adalah proses dimana semua kegiatan pengelolaan keuangan desa dipertanggung- jawabkan oleh pemerintah desa.

\section{Anggaran Pendapatan dan Belanja Desa (APBDes}

Menurut sumpeno (2015:35) APBDes merupakan suatu rencana keuangan tahunan desa yang ditetapkan berdasarkan peraturan desa yang mengandung prakiraan sumber pendapatan dan belanja untuk mendukung kebutuhan program pembangunan desa yang bersangkutan.

\section{Pendapatan}

Pendapatan desa meliputi semua penerimaan uang melalui rekening kas desa yang merupakan hak desa dalam satu tahun anggaran yang tidak perlu dibayar kembali oleh desa (Pemendagri Nomor 113 Tahun 2014).

\section{Belanja Desa}

Belanja desa adalah semua pengeluaran dari rekening desa yang merupakan kewajiban desa dalam satu tahun anggaran yang tidak akan diperoleh atau tidak 
diharapkan pembayarannya kembali oleh desa. Belanja desa diproritaskan untuk memenuhi kebutuhan pembangunan yang disepakati dalam musyawarah desa dan sesuai dengan prioritas pemerintah daerah kabupaten/kota, pemerintah daerah provinsi dan pemerintah (UU Nomor 6 tahun 2014).

\section{METODE PENELITIAN}

Penulis memilih untuk menggunakan penelitian kualitatif dikarenakan dalam penelitian ini menjelaskan tentang proses pengelolaan APBDes mulai dari tahapan perencanaan hingga pertanggungjawaban. Jenis dan sumber data yang digunakan dalam penelitian ini yaitu primer dan sekunder. Teknik pengumpulan data yang dipilih penulis adalah wawancara, observasi, dan dokumentasi. Teknik analisis data dalam penelitian ini yaitu reduksi data, penyajian data, dan penarikan kesimpulan.

\section{HASIL DAN PEMBAHASAN}

Anggaran Pendapatan dan Belanja Desa (APBDes) adalah instrumen penting yang sangat menentukan dalam rangka mewujudkan tata pemerintahan yang baik dalam pelaksanaan pembangunan di tingkat desa. Tata pemerintahan yang baik, dapat diukur dari proses pengelolaan APBDes, dimulai dari proses perencanaan hingga pertanggungjawaban APBDes. Akuntabilitas dalam pengelolaan anggaran pendapatan dan belanja desa (APBDes) merupakan upaya mewujudkan tata kelola keuangan pemerintah desa yang sesuai dengan azas good governance. Anggaran Pendapatan dan Belanja Desa sebagai sebuah dokumen publik sudah seharusnya disusun dan dikelola berdasarkan prinsip partisipatif, transparan, dan akuntabel.

\section{Perencanaan Anggaran Pendapatan Dan Belanja Desa (APBDes)}

Berdasarkan hasil wawancara dengan sekretaris desa Bluru Kidul melaksanakan musyawarah dengan RT/RW terlebih dahulu sebelum diselenggarakan di musyawarah desa. usulan RT/RW tersebut akan menjadi skala prioritas yang akan dibawa ke musyawarah desa. pemerintah desa melakukan Musyawarah tingkat RT/RW kemudian akan dibawa ke musyawarah desa apa yang penting akan didahulukan dan yang tidak penting mungkin akan dilaksanakan di tahun berikutnya. Kemudian dari hasil musyawarah dusun tersebut akan diajukan oleh kepala dusun ke musyawarah desa untuk dibahas bersama perangkat desa, kepala dusun lainnya.

\section{Pelaksanaan Anggaran Pendapatan Dan Belanja Desa (APBDes)}

Dari Hasil wawancara dengan sekretaris desa menunjukkan bahwa dalam pelaksanaan APBDes senantiasa dilaporkan perkembangan kegiatan oleh pihak pelaksana pembangunan desa. terutama kegiatan fisik dan penyerapan dana. Setiap kegiatan yang dilakukan pihak pelaksana harus melaporkannya dan disertai foto kegiatan dan perkembangan pembangunan sedangkan dokumen pengeluaran 
harus disertai dengan bukti pembelian yang berupa nota pembelian, faktur pembelian, dan bukti yang sah.

\section{Penatausahaan Anggaran Pendapatan Dan Belanja Desa (APBDes)}

Berdasarkan hasil wawancara tersebut yang dilakukan peliti, bendahara Desa Bluru Kidul sudah melaksanakan tugas penatausahaan sesuai peraturan yang berlaku. Dalam penatausahaan Bendahara desa dan pihak perencanaan yang melengkapi dalam pengelolaan administrasi keuangan desa. Bendahara Desa memiliki buku kas, buku bank, dan kas pembantu pajak dalam pencatatan penerimaan dan pengeluaran desa. Bendahara juga melakukan tutup buku setiap akhir bulan secara tertib dan mempertanggungjawabkan hasil pengelolaan keuangannya melalui laporan pertanggungjawaban setiap bulannya kepada Kepala Desa. Sekretaris desa terlebih dahulu melakukan verifikasi guna meneliti kelengkapannya. Selanjutnya kepala desa menyetujui surat perintah pembayaran yang telah diverifikasi dan kemudian bendahara desa mengeluarkan dana dari kas desa untuk melunasi tagihan-tagihan tersebut. Setiap akhir tahun bendahara akan melakukan tutup buku. Bendahara desa sebaiknya bisa mempertanggungjawabkan pengelolaan uang kas desa dalam laporan pertanggungjawaban dan dilaporkan kepada kepala desa.

\section{Pelaporan dan Pertanggungjawaban APBDes}

Berdasarkan hasil wawancara diatas dapat diketahui bahwa pembinaan dan pengawsan dari inspektorat sangat diperlukan guna mendukung penerapan prinsip akuntabilitas pada pertangggungjawaban APBDes untuk pembangunan desa yang lebih baik dan kesejahteraan masyarakat. Namun dalam hal pertanggungjawaban APBDes masih terdapat kelemahan yakni belum optimalnya transparansi dalam pertanggungjawaban APBDes. Sehingga perlu untuk pengawasan inspektorat,dinas yang terkait dan kecamatan.

Perencanaan APBDes tidak selalu sesuai dengan pelaksanaannya. Maka dari itu pemerintah desa melakukan perubahan APBDes guna menyesuasikan dengan realita yang terjadi. Perubahan APBDes dapat dilakukan apabila terjadi perkembangan yang tidak sesuai dengan asumsi kebijakan umum APBDes, atau keadaan yang menyebabkan harus dilakukan pergeseran anggaran kegiatan dan jenis belanja. Hasil perubahan tersebut disebut perubahan anggaran kerja (PAK) dan dimasukkan dalam laporan pertanggungjawan APBDes. Perubahan APBDes desa bluru kidul tersebut dibuktikan dalam hasil wawancara berikut:

"iya setiap perencanaan ada perubahan terkait dengan kegiatan. Mungkin ada kekurangan atau kelebihan kegiatan pasti ada perubahan APBDes nya nah biasanya karena ada kekeliruan tapi tetap dimasukkan dalam perubahan anggaran kerja dan akhir tahun akan mengadakan perubahan anggaran kerja” 
Tabel 1. Data Hasil Pertanggungjawaban APBDes

\begin{tabular}{lrrrr}
\hline \multicolumn{1}{c}{ Uraian } & \multicolumn{2}{c}{ Anggaran } & \multicolumn{1}{c}{$\begin{array}{c}\text { Bertambah/ } \\
\text { Berkurang }\end{array}$} \\
\cline { 2 - 3 } & \multicolumn{1}{c}{ Sebelum PAK } & \multicolumn{1}{c}{ Setelah } & \\
\hline Pendapatan desa & $2.106 .179 .338,00$ & $2.178 .638 .202,03$ & & $72.458 .864,03$ \\
Belanja desa & $2.607 .091 .414,00$ & $2.814 .600 .278,03$ & & $207.508 .864,03$ \\
Pembiayaan desa & $635.962 .075,55$ & $635.962 .075,55$ & & 0,00 \\
\hline
\end{tabular}

Sumber: Data Olahan Peneliti

Hasil dari wawancara diatas diperkuat dengan data hasil pertanggungjawaban APBDes (Tabel 1).

Dari hasil penelitian tersebut di atas dapat disimpulkan bahwa sistem akuntabilitas pengelolaan APBDes di desa bluru kidul sudah berdasarkan pada prinsip akuntabilitas.

Setiap dana yang dikeluarkan pemerintah merupakan produk politik. Sehingga terjadi tarik ulur kepentingan antar pihak yang berkepentingan, pihak yang berkepentingan adalah pemerintah desa dan masyarakat desa.

\section{SIMPULAN}

Berdasarkan hasil penelitian yang telah dilakukan di desa Bluru Kidul Kecamatan Sidoarjo sudah memenuhi prinsip akuntabilitas mulai dari perencanaan, pelaksanaan, penatausahaan, pelaporan, dan pertanggungjawaban sudah berjalan dengan baik. Namun masih ada beberapa hal yang belum efektif sebagai berikut: (1) Pemerintah desa yang belum transparan terhadap masyarakat agar masyarakat desa mengetahui program-program kerja dalam satu tahun dan berapa banyak dana desa yang dikeluarkan dalam pembangunan desa. sehingga dibutuhkannya pengawasan dan pembinaan dana desa guna untuk menghindari adanya korupsi dana desa. Dengan demikian, pemerintah desa bluru kidul kecamatan sidoarjo belum dapat dikatakan pemerintahan yang good governance. (2) Pemerintah desa bluru kidul masih belum dapat mempertanggungjawabkan laporan pertanggungjawaban APBDes dengan baik. Dan masih sering terjadinya keterlambatan laporan realisasi pertanggungjawaban. Hal ini dikarenakan adanya perubahan peraturan perdes yang mengakibatkan pemerintah desa sulit untuk menyusun laporan realisasi pertanggungjawaban. Saran dalam penelitian ini adalah (1) Diharapkan kepala desa beserta perangkatnya mampu mengelola anggaran dana desa dengan sebaik-baiknya dan transparan. Kegiatan sosialisasi itu diharapkan dapat menjadi wawasan baru bagi para kepala desa dan perangkatnya. (2) Pada tahun berikutnya diharapkan perangkat desa menggunakan Dana desa hendaknya transparan dana desa agar warga tahu untuk apa dana itu digunakan, juga untuk menghindari permasalahan di kemudian dan mengikuti proses pengadaan barang/jasa pemerintah sesuai dengan peraturan perundangan yang berlaku. (3) Diharapkan Dinas Pemberdayaan Masyarakat Desa, Badan Pengelola Keuangan Daerah, Bapperda, Inspektorat dan Bappenda untuk melakukan pembinaan dan pengawasan sehingga implementasi terkait 
kebijakan dana desa berjalan dengan baik dan realisasi pelaksanaan kegiatan pembangunan di desa bisa menjadi optimal dan penggunaan dana desa bisa tepat sasaran. (4) Diharapkan pemerintah desa secepatnya dapat menyusun laporan realisasi pertanggungjwaban pengelolaan APBDes dengan baik dan tetap menggunakan peraturan perdes yang berlaku. Secepatnya perangkat desa dapat mempertanggungjawabkan laporan realisasi pertanggungjawaban secepatnya pula penyerapan anggaran tahun berikutnyadapat terealisasikan.

\section{DAFTAR PUSTAKA}

Ari, Anies 2017, Transparansi Dan Akuntabilitas Pemerintah Desa Dalam Pengelolaan Dan Pertanggungjawaban Anggaran Pendapatan Dan Belanja Desa (APBDes), Soedirman Accounting Review, Universitas Peradaban.

Peraturan Menteri dalam Negeri Nomor 113 Tahun 2014 tentang Pengelolaan Keuangan Desa.

Sumpeno, Wahjudin. 2015. Perencanaan Desa Terpadu. Banda Aceh: Read. Undang - Undang No 6 Tahun 2014 Tentang Desa

Waluyo. 2007. Manajemen Publik (Konsep, Aplikasi, dan Implementasinya dalam Pelaksanaan Otonomi Daerah). Bandung: CV. Mandar Maju. 